\title{
Structure and Topography of the Thymus in the European Beaver
}

\author{
Krystyna WYRZYKOWSKA \& Zygmunt WYRZYKOWSKI
}

\begin{abstract}
Wyrzykowska K. \& Wyrzykowski Z., 1979: Structure and topography of tne tnymus in the European beaver. Acta theriol., 24, 29: 399-404 1With Plates II-III].

Examination was made of the micro- and macroscopic structure of the thymus and its position in 17 European beavers (Castor fiber Linna e us, 1758) of both sexes, varying in age from one day to one year. The results obtained were compared with analogical data relating to other species of animals.

[Inst. Fundament. Vet. Sci., Agric. Tech. Acad., 10-957 Olsztyn, Poland].
\end{abstract}

\section{INTRODUCTION}

Studies have been carried out for many years on the histomorphology of the thymus in different species of animals, including rodents. The majority of the papers published are concerned with the structure of this organ in laboratory animals (G ree n, 1955; S a n e l, 1965; K ostowiecki, 1962), or small wild rodents (B a zan-Kubik, 1961; $\mathrm{Bazan-Kubik}$ \& Karpowicz, 1969). There are, however, no papers providing exhaustive information on this organ in larger rodents such as, for instance, the beaver or nutria, although there have been several monographs on the anatomy of these animals ( $\mathrm{H}$ in z e, 1950; $\mathrm{K} \mathrm{o} \mathrm{ch}$, 1953). In view of the foregoing, and as material was available, studies were undertaken on the thymus in the beaver, paying particular attention to the topography and microscopic structure of this organ.

\section{MATERIAL AND METHODS}

The thymus glands of 17 beavers of both sexes, varying in age from one day to one year, were used for the studies. The animals were obtained from the Polish Academy of Sciences Experimental Station at Popielno and the Fur Farm at Wiartel.

The location of the thymus was defined after preliminary preparation, then the gland was completely prepared and weighed, sectioned, fixed in AFA fluid or $10 \%$ formalin, and $6 \mu \mathrm{m}$ paraffin sections were given routine staining $\mathrm{H}$ and $\mathrm{E}$ treatment. 
In the beaver the thymus consists of a paired pars cervicalis thymi and pars thoracalis thymi. Pars cervicalis is formed of two lobes which adhere symmetrically to $\mathrm{mm}$. sternohyoidei and $\mathrm{mm}$. sternocephalici. The posterior margins of the lobes are situated at the level of the entrance to the thorax. From the ventral side the lobes of pars cervicalis thymi are covered with a very large serous salivary gland with which they are connected with loose connective tissue, and covered with subcutaneous tissue and skin (Photo. 1, 2, 3).

Pars thoracalis thymi is situated in the lower part of the anterior mediastinum. The anterior margin reaches the place of departure from the aortic arch of $a$. brachiocephalica and $a$. carotis communis sin. It covers part of the aortic arch and pulmonary artery. The posterior margin reaches the base of the heart, partly covering the auricle. It is connected with the pericardium by loose connective tissue (Photo. 3 ).

\subsection{Macroscopic Structure}

In the cervical part the thymus forms two separate lobes, left and right, oval in shape, flattened dorsoventrally. The lobes have distinct lobular structure visible under the thin, but well-formed connective tissue capsule. The dark brown lobules are separated by light-coloured bands of connective tissue. The edges of the lobules are blunt and regular in outline (Photo. 4).

Pars thoracalis thymi is usually an unpaired, irregularly shaped, weakly formed capsule of connective tissue, loose in structure. It was only in two individuals that a septum of loose connective tissue was observed, separating pars thoracalis thymi into two separate lobes.

The lobular structure is almost invisible and the light pink colour of the lobules blends with the interlobular connective tissue. It is therefore often difficult macroscopically to recognize and distinguish the thymus from the tissues surrounding it, particularly in older animals. In the two newborn individuals two small processes were observed reaching cephalad to the branching of the $a$. brachiocephalica from the anterior margin of the thymus (Photo. 3).

The average weight of the thymus in day-old and one-year-old beavers is as follows:

\begin{tabular}{lcc}
\hline & day-old animals & one-year-old animals \\
\hline pars cervicalis, g & $2.03(1.45-2.60)$ & $2.8(1.8-3.0)$ \\
pars thoracalis, g & $1.2(0.65-1.75)$ & $1.5(0.9-2.0)$ \\
Combined wt. of thymus, g & 3.23 & 4.4. \\
\hline
\end{tabular}


The thymus forms $0.58 \%$ of the body weight of day-old beavers weighing on an average $555 \mathrm{~g}$, and $0.04 \%$ in year-old beavers weighing $10,700 \mathrm{~g}$.

\subsection{Microscopic Structure}

In beavers, as in other mammals, the thymus consists of lobules in which there is distinct division into the cortical part, with densely arranged and deeply-staining thymocytes, and the medullary part with large, loosely distributed cells which stain more faintly, among which it was possible to distinguish large and medium-sized thymocytes, reticular cells and corpuscula thymi.

Between the lobes there are thick bands of connective tissue with numerous blood vessels. These are mostly large and medium-sized venous vessels filled with formed blood components (Photo. 5).

The branchings of the interlobular arterioles come within the lobules, where they form a capillary network. Cross-sections of the capillaries containing single erythrocytes can be seen in both the cortical and medullary parts of the lobules. In addition on the boundary between cortex and medulla numerous cross-sections of small venules or capillaries of the sinusoid type can be seen.

The lobules of the thymus in beavers are differentiated in respect of shape and size. Seen under a microscope small and medium-sized lobules predominate, with compactly built cortex and oval or strongly elongated shapes (Photo. 5). Large lobules, with deep indentations reaching as far as the medullary part, form only a small percentage of the whole.

Numerous evenly distributed corpuscula thymi, which gland is characterized by considerable polymorphism, can be seen in the medulla (Photos. 6, 7, 8). Round or oval corpuscula thymi are most often observed, with distinct concentrical arrangement of cells, and a homogeneous vitreous structure of the corpusculum centre (Photos. 6, 7).

Single or double corpuscula thymi of a second type are also encountered in which, unlike those described above, there is a space round the centre filled with thymocytes and cell detritus, and a wall formed of flat, strongly eosinophilic reticular cells separating the detritus from the medullary tissue (Photo. 8).

The dimensions of corpuscula thymi, even within one lobule, vary within very wide limits from $47.5 \times 38.0$ to $263.2 \times 190.0 \mu \mathrm{m}$ (Photos. 6,7 ). 


\section{DISCUSSION AND CONCLUSIONS}

Thymus glands composed of pars cervicalis and pars thoracalis such as those observed in the beaver, occur extremely rarely in other mammals.

In the majority of species there is usually one well-developed part, while the second part disappears completely during the development period (Nickel, Schummer \& Seiferle, 1976).

The from most often encountered is the bilobular thymus situated in the mediastinum in the region of the heart ( $\mathrm{Gr}$ e e $\mathrm{n}, 1955 ; \mathrm{H}$ a gström, 1921; B a z a n-K ubik, 1961; B a z a n-Kubik, 1969), or in the proximal part of the thorax ( $\mathrm{B} \mathrm{a} \mathrm{z} \mathrm{a} \mathrm{n,} \mathrm{1952).}$

It is only in the water shrew that the thymus, like that in the beaver, consists of pars cervicalis and pars thoracalis, the cervical part being situated near the thyroid, while the thoracic part covers the lungs and heart ( $\mathrm{B}$ a $\mathrm{z}$ a n, 1955).

In the beaver the two parts of the thymus form completely independent lobes, although during the foetal period they may still be connected by isthmus cervicothoracalis, as is proved by the processes, observed in the two newborn beavers, running cephalad from pars thoracalis thymi (Photo. 3).

Pars cervicalis attains a greater weight, has more deeply stained lobules, standing out very distinctly from the light-coloured interlobular connective tissue, and very numerous cross-sections of vessels observed in the microscopic picture. All the above indicates quite clearly that this part of the thymus is more active functionally than pars thoracalis.

A characteristic feature of the thymus in the beaver consists of lobules with smooth margins, without deep indentations secondarily dividing the lobules, clearly differentiated into pars corticalis and pars medullaris, irrespective of the age of the animal examined. A large number of corpuscula thymi with the structure typical of that observed in other mammals, and a large number of blood vessels.

Corpuscula thymi of the second type described in literature for the guinea pig (K o s to w i e c k i, 1962) and also in birds (W y r z y kow ski, 1978) were also observed.

In accordance with the opinion put forward by Ko s to w i e c k i (1962) it may be assumed that these corpuscule form a highly effective apparatus destroying and disposing of the medullary tissue of the thymus. The presence of these corpuscula in the thymus gland in one-year-old beavers may therefore be considered as one of the manifestations of the onset of involution (W y rzy kowska \& Wyrzykowski, 1978).

The microscopic picture of the beaver thymus is in general similar 
to analogical organs in other species of mammals and birds ( $\mathrm{Nickel}$ et al., 1976; Wy rzykowski, 1978). The differences present relate to the shape of the lobules, number of blood vessels and structure of corpuscula thymi.

Bazan (1952, 1955), Bazan-Kubik (1961a, b), and BazanKubik \& Karpowicz (1969) drew attention to the absence of differentiation into cortical and medullary parts, indistinct division into lobules and non-typical structure of corpuscula thymi in small mammals. At the same time the authors stated that the histological picture of these animals depends on different factors, including season and age. For instance in Micromys minutus in winter the lobular structure, and division into cortex and medulla, are effaced and corpuscula thymi disappear (B a z a n-K u bik, 1961a).

The material is not sufficiently abundant to obtain an unequivocal reply as to whether changes of this kind can be observed in the picture of beaver thymus glands in animals bred in beaver farms, that is, under artificial conditions. However, these factors play a lesser part in the case of beavers and the microscopic picture of this organ changes depending primarily on age, when the process of involution begins (Wyrzykowska \& Wyrzykowski, 1978).

\section{REFERENCES}

1. B a z a n I., 1952: Zmiany morfohistologiczne grasicy u Sorex araneus L. w cyklu życiowym. Annls Univ. Mariae Curie-Skłodowska, C, 7: 253-304.

2. B a zan I., 1955: Badania nad zmiennością aparatu płciowego i grasicy u rzęsorka rzeczka (Neomys fodiens fodiens Schreb.). Annls Univ. Mariae Curie-Skłodowska, C, 9: 213-259.

3. B a zan-Kubik I., 1961a: Zmienność grasicy badylarki Micromys minutus (Pallas 1771). Acta theriol., 4: 285-287.

4. B a z a n-K ubik I., 1961b: Zmiany morfohistologiczne niektórych narządów Mus musculus Linnaeus $1758 \mathrm{z}$ kopalni węgla. Acta theriol., 8: 99-113.

5. B a z a n-K u bik I. \& Karpowicz M. J., 1969: Zmienność morfohistologiczna grasicy Apodemus flavicollis (Melchior 1834). Annls Univ. Mariae Curie-Skłodowska, C, 15: 239-254.

6. Green E. C., 1955: Anatomy of the rat. Hafner: 1-370. New York.

7. Hagström M., 1921: Die Entwicklung des Thymus beim Rind. Anat. Anz., 53: $545-566$.

8. Hinze G., 1950: Der Biber. Akademische Verlag: 1-214. Berlin.

9. Koch T., 1953: Beiträge zur Anatomie der Sumpfbibers. S. Hirzel Verlag: $1-68$. Leipzig.

10. Kostowiecki M., 1962: Development and degeneration of the second type of Hassall's corpuscles in the quinea pig. Anat. Rec., 142: 195-203.

11. Nickel R., Schummer A. \& Seiferle E., 1976: Lehrbuch der Anatomie der Haustiere. Verlag Paul Parey, 3, 1: 292-302. Berlin und Hamburg.

12. Sanel F. T. Copenhaver W. M., 1965: Histogenesis of mouse thymus studied with the light and electron microscope. Anat. Rec., 151: 410-415. 
13. Wyrzykowski Z., 1978: Ciałka grasicy drugiego typu u niektórych gatunków ptaków domowych. Folia Morph., 1: 113-120.

14. Wyrzykowska K. \& Wyrzykowski Z., 1978: Histomorfologia inwolującej grasicy bobra europejskiego (Castor fiber L. 1758). Zesz. nauk. ART Olszt., Wet., 10: $85-97$.

Accepted, March 12, 1979.

\section{Krystyna WYRZYKOWSKA i Zygmunt WYRZYKOWSKI BUDOWA I TOPOGRAFIA GRASICY BOBRA EUROPEJSKIEGO}

Badano grasicę bobra europejskiego, określając jej położenie oraz makro i mikroskopową budowę u 17 osobników tego gatunku w wieku od pierwszego dnia po urodzeniu do 1 roku. Stwierdzono, że grasica bobra składa się z części szyjnej i piersiowej nie połączonych ze sobą. Obie te części mają podobną budowę mikroskopową. Zbudowane są z zaokrąglonych, owalnych lub wydłużonych zrazików, o równych brzegach oddzielonych pasmami tkanki łącznej (Fot. 5). Obwodową częśé urazika wypełniają ciasno tymocyty nadając jej ciemne zabarwienie. Część rdzeniowa barwi się jaśniej (Fot. 5). Bardzo liczne i duże ciałka grasicy (corpuscula thymi) bobra budową przypominają podobne u innych gatunków ssaków (Fot. 6, 7). Mają szkliste lub zwapniałe centrum wokół którego koncentrycznie układają się komórki siateczki. Obok typowych ciałek występują również ciałka grasicy drugiego typu (Fot. 8).

\section{Explanations of Plates II-III}

Plate II

Photo. 1. Uncovered lobes of the cervical thymus of a 8 months old beaver Magn. $0.4 \times 1$.

1 - lobes of the thymus, 2-the salivary gland, 3-sternocephalic muscles, $4-$ sternohyoid muscles.

Photo. 2. The thymus and salivary gland junction of a 6 months old beaver. Magn. $80 \times$.

Photo. 3. Topography of the thoracal thymus of a 6 months old beaver. Magn. $0.8 \times 1$.

1 - the thoracal thymus with rudimentary processes, 2 - the cervical thymus. Photo. 4. Lobes of the cervical thymus of a 6 months old beaver.

Plate III

Photo. 5. Cervical thymus of an one day old beaver.

1-medulla thymi, 2-cortex thymi, 3-thymus corpuscle (Hasall's), 4-interlobular blood vessels.

Photo. 6. Giant thymic corpuscle (Hassall's) of an one day old beaver. Magn. $500 \times$. Photo. 7. Thymic corpuscles (Hassall's) in the thymic lobulus of an one day beaver. Magn. $500 \times$.

Photo. 8. Second type thymic (Hassall's) corpuscle of an one day old beaver. Magn. $500 \times$. 


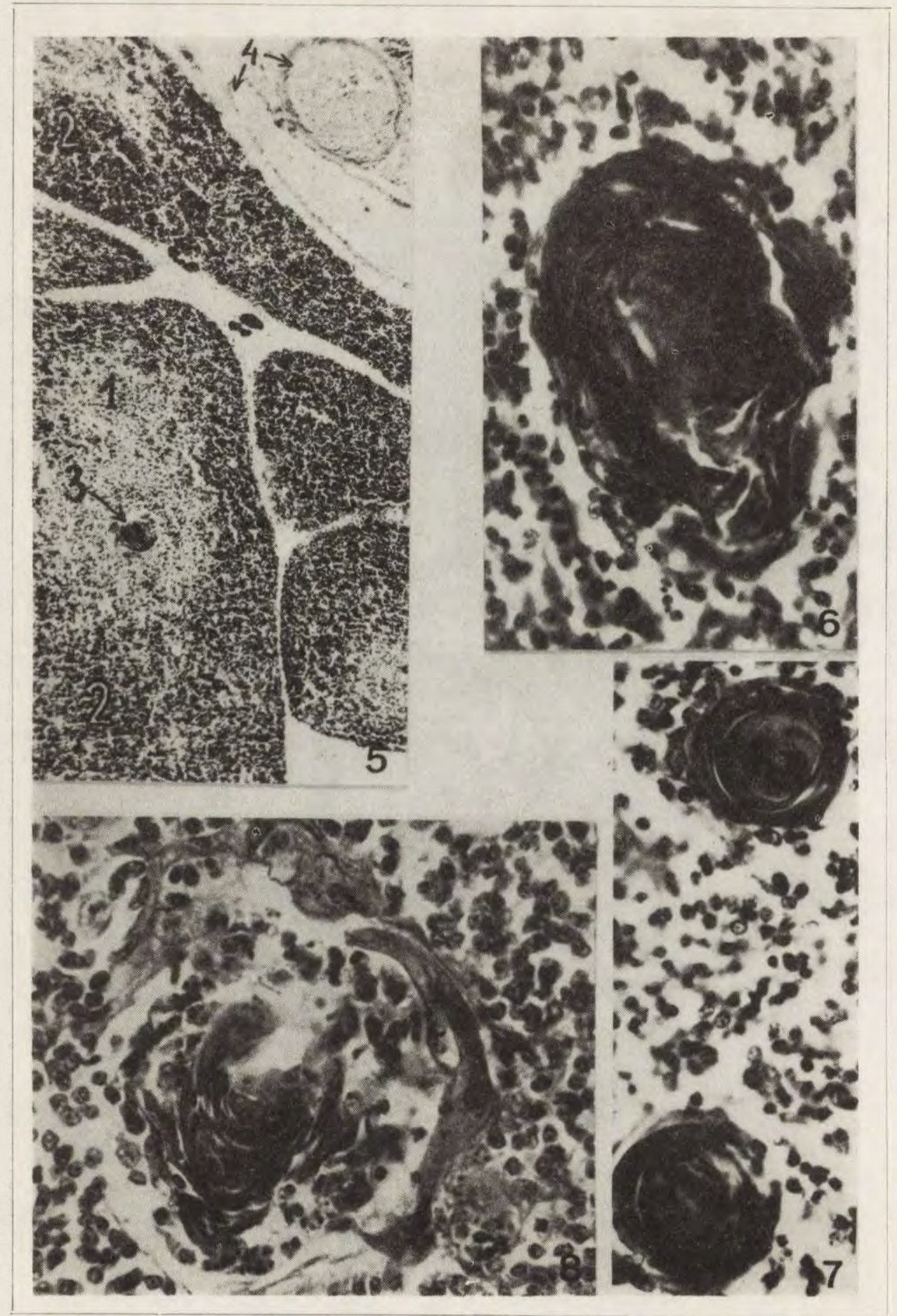

K. Wyrzykowska \& Z. Wyrzykowski

C. Nagięć phot. 
ACTA THERIOLOGICA, Vol. XXIV, 29.

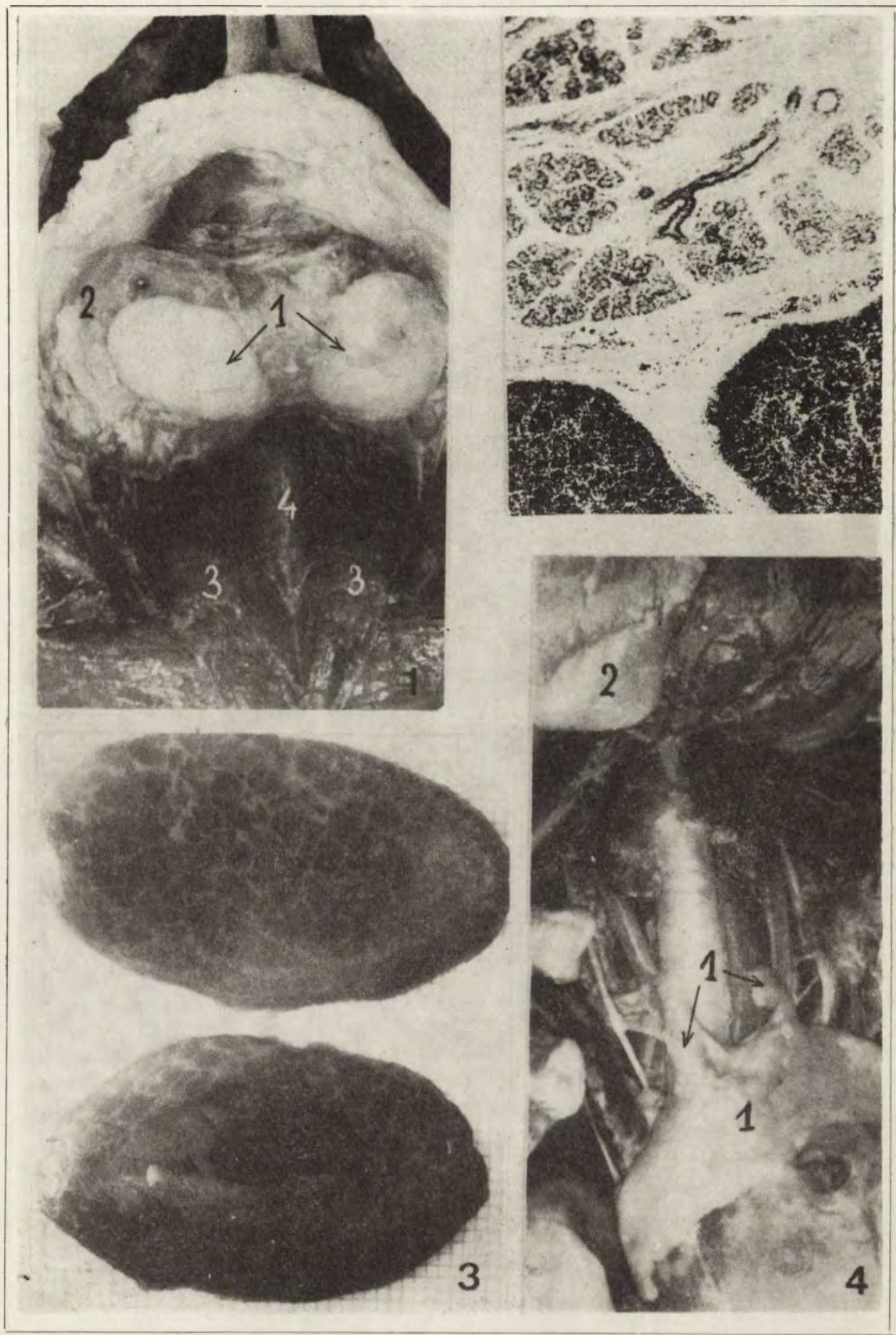

K. Wyrzykowska \& Z. Wyrzykowski

C. Nagięć phot. 